\title{
Gambaran Ketangguhan Ibu dalam Mengasuh Anak Autis
}

\author{
Nurussakinah Daulay ${ }^{1}$ \\ Universitas Islam Negeri (UIN) Sumatera Utara
}

\begin{abstract}
This study aimed to look at the profile picture of hardiness in mothers of children with autism in the city of Medan. A total of 58 mothers were included in this study. Sampling was done by purposive sampling. The method was used to descriptive quantitative method. Data were taken using a measuring instrument such as Hardiness scale (Dispositional Resilience Scale/DRS-15). Processing and analysis of statistical data was descriptive, meaning that findings such as demographic data, aspects of hardiness and other additional data will be analyzed in the form of a minimum score, maximum score, mean and standard deviation, in order to illustrate the hardiness profile comprehensively. The results showed that the picture of the strength of the mothers of children with autism in average level. Judging from the hardiness, found that aspects of the commitments had the highest mean score, followed by the control aspect and the aspect of the challenge.
\end{abstract}

Keywords: children with autism; mother; hardiness

Abstrak: Penelitian ini bertujuan untuk melihat gambaran profil ketangguhan pada ibu yang memiliki anak autis di kota Medan. Sebanyak 58 ibu-ibu dilibatkan dalam penelitian ini. Pengambilan sampel dilakukan dengan purposive sampling. Metode yang digunakan adalah metode kuantitatif deskriptif. Data diambil dengan menggunakan alat ukur berupa skala Ketangguhan (Dispositional Resilience Scale/DRS-15). Cara pengolahan dan analisa data statistik bersifat deskriptif, artinya temuan seperti data demografi, aspek ketangguhan dan data tambahan lainnya akan dianalisa berupa skor minimum, skor maksimum, mean dan standar deviasi, agar dapat menggambarkan profil ketangguhan secara komprehensif. Hasil penelitian menunjukkan bahwa gambaran ketangguhan pada ibu yang memiliki anak autis berada dalam kategori sedang. Ditinjau dari aspek ketangguhan yang dikemukakan oleh Maddi \& Kobasha (1980), ditemukan bahwa aspek komitmen memiliki nilai mean tertinggi, kemudian diikuti dengan aspek kontrol dan aspek tantangan. Implikasi penelitian ini sebagai data awal untuk melihat gambaran profil ketangguhan ibu dalam mengasuh anak autis di kota Medan.

Kata kunci: anak autis; ibu; ketangguhan

Anak yang mengalami gangguan perkembangan seperti autis merupakan anak yang secara signifikan berbeda dari segi tingkah laku, emosi, kognitif atau sosial. Beberapa karak-

Korespondensi mengenai isi artikel ini dapat dilakukan melalui email: ${ }^{1}$ nurussakinah.daulay@mail. ugm.ac.id

PSIKOHUMANIORA: Jurnal Penelitian Psikologi — I SSN: 2502-9363 (p); 2527-7456 (e) 


\section{Nurussakinah Daulay}

teristik gangguan dengan spektrum autis adalah penurunan hubungan timbal balik dalam berinteraksi sosial, gangguan dalam verbal dan non verbal keterampilan berkomunikasi, dan perilaku serta minat berulang (APA, 2014; Matson, Hess, Neal, Mahan \& Fodstad, 2010; Matson, Kozlowski, Hattier, Horovitz, \& Sipes, 2012). Penurunan dalam interaksi sosial dapat diwujudkan melalui rendahnya timbal balik sosial atau emosional, kurangnya spontan berbagi pengalaman dengan orang lain, dan kurangnya perilaku non verbal seperti kontak mata, ekspresi wajah, dan postur tubuh (Volkmar, Siegel, Woodbury, King, McCracken \& State, 2014). Penurunan kemampuan komunikasi dapat diwujudkan melalui keterlambatan atau kurangnya perkembangan bahasa atau pola berbicara yang aneh seperti volume terlalu tinggi (Hattier \& Matson, 2012). Kasus klasik gangguan perkembangan autis dikarakteristikkan dengan kurangnya kontak mata, respon wajah, atau tersenyum, serta oleh kegagalan untuk menanggapi suara orang tua (APA, 2014; Holzer, et al., 2006).

Jumlah anak autis pada setiap negara di seluruh dunia ini terus meningkat. Penelitian yang dilakukan oleh Kristine, dkk, (2014) mengemukakan bahwa prevalensi gangguan spektrum autis terus meningkat, dan diperkirakan prevalensi sekitar 1\% dari keseluruhan populasi (Baird, et al,2006). Berikut adalah laporan jumlah prevalensi autis di Amerika Serikat menurut dari Centers for Disease Control and Prevention (2014).

Tabel 1.

Jumlah prevalensi autis di Amerika Serikat

\begin{tabular}{ll}
\hline Tahun & Jumlah \\
\hline 2002 & $1: 150$ \\
2006 & $1: 110$ \\
2008 & $1: 88$ \\
2012 & $1: 68$ \\
\hline
\end{tabular}

Peningkatan angka ini menunjukkan bahwa autis sebagai sebuah masalah kesehatan utama di Amerika Serikat (King and Bearman 2009; Newschaffer \& Curran 2003; Rossi, et al, 2013, dalam Krissy, et al , 2012). Tidak hanya di Amerika Serikat saja, namun di Indonesia juga terjadi peningkatan jumlah individu yang mengalami autis. Yayasan Autis Indonesia menyatakan adanya peningkatan prevalensi autis, di mana jumlah anak autis di Indonesia diperkirakan 1 : 5000 anak, meningkat menjadi 1 : 500 anak Pada tahun 2000, staf bagian Psikiatri Fakultas Kedokteran Universitas Indonesia memperkirakan terdapat kurang lebih 6.900 anak-anak autis di Indonesia (Moore, 2010). Penelitian yang dilakukan Stefani (2012) terhadap anak autis di kota Medan, diperkirakan jumlah anak autis yang lahir mencapai 250 


\section{Gambaran Ketangguhan Ibu dalam Mengasuh Anak Autis}

orang pertahun dan akan terus bertambah dari tahun ke tahun (data tahun 2012) (http://repository.usu.ac.id/handle/123456789/31119).

Berdasarkan jumlah prevalensi anak yang mengalami gangguan perkembangan autis terus meningkat, serta permasalahan pada gangguan ini lebih kompleks dibandingkan gangguan perkembangan lainnya, akan semakin banyak pula orang tua yang mengalami konflik batin dalam menerima keberadaan anaknya yang autis. Konflik ini terjadi karena adanya kesenjangan antara harapan orang tua yang tidak terpenuhi dan kenyataan untuk memiliki anak yang dapat dibanggakan dalam keluarga, sehingga orang tua menerima anaknya yang autis. Dengan demikian, anak autis membutuhkan pelayanan dan pengasuhan yang ekstra dari keluarga dan masyarakat. Keluarga khususnya orang tua merupakan orang terdekat bagi anak autis, bagi orang tua sendiri awalnya dengan ketidakpastian diagnosa dan penyebab autis dikombinasikan dengan tekanan emosi yang terkait dengan penanggulangan gejala anak autis seperti masalah dalam berkomunikasi, ekspresi emosi dan perilaku antisosial dapat menimbulkan pengalaman penuh stres bagi orang tua (Dale, et al , 2006; Gray, 1994).

Autis merupakan gangguan perkembangan yang berat serta terjadi sepanjang kehidupan, namun perilaku ini dapat dikurangi dengan adanya penanganan dan pengasuhan yang tepat dari orang tua, keluarga, dan masyarakat. Usaha-usaha yang tepat dilakukan terhadap anak autis akan memengaruhi tumbuh kembangnya menjadi lebih baik dan berdaya guna. Keluarga khususnya ibu merupakan figur yang sangat penting berpengaruh dalam proses tumbuh kembang anak. Ibu yang mendidik dan merawat anak dengan kehangatan tentu akan lebih berdampak positif pada anak dibandingkan dengan ibu yang melakukannya sebagai tugas ataupun hanya keharusan semata tanpa melibatkan kehangatan. Harapannya pada ibu yang memiliki anak autis mampu menerima kondisi keterbatasan anaknya, memiliki pengetahuan, kesabaran serta penyesuaian diri positif dalam merawat dan menyikapi segala permasalahan selama mengasuh anak autis. Ibu yang sudah bisa menyesuaikan dengan kondisi anaknya dan mampu menerima dengan keterbatasan anaknya maka akan menumbuhkan nilai-nilai positif dalam diri ibu. Disinilah letak pentingnya kepribadian tangguh sebagai kekuatan internal ibu agar tetap sehat di bawah tekanan permasalahan anak. Hal ini senada dengan penelitian dari Fitzgerald, dkk, 2002; Tomanik, dkk, 2004, dalam Estes, dkk, 2009) bahwa keberfungsian adaptif lebih baik pada anak-anak jika dihubungkan dengan peningkatan kesejahteraan pengasuhan ibu.

Maddi \& Kobasa telah mengemukakan konsep kepribadian tangguh sejak tahun 1970an, dimulai dari penelitian yang intensif dan longitudinal dari Maddi dan Kobasa (dalam 


\section{Nurussakinah Daulay}

Maddi, 2006) pada para manajer di perusahaan Illinois Bell Telephone (IBT). Sejak itu konsep ketangguhan ini terus berkembang sebagai salah satu konsep yang mendukung perkembangan kesehatan mental manusia. Suzanne Kobasa (Kobasa, 1979; Kobasa, Maddi, \& Kahn, 1982) menguji sumber koping dengan melihat penyakit fisik sebagai sebuah indikator koping yang rendah. Kobasa menemukan bahwa seseorang dengan kepribadian tangguh ditunjukkan antara mental yang baik dan sehatnya fisik (Kobasa, et al ., 1994).

Kobasa (dalam Maddi, 2006) menekankan bahwa ketangguhan dideskripsikan sebagai gaya atau pola kepribadian yang terkait dengan kesehatan dan performa di bawah stres. Seseorang yang tangguh memiliki komitmen kerja, memiliki perasaan bahwa apapun yang terjadi berada di bawah kontrol orang tersebut, dan terbuka terhadap perubahan dan tantangan dalam hidup. Mereka cenderung menginterpretasikan kejadian yang menekan dalam hidup sebagai sesuatu hal yang menarik untuk dihadapi. Secara singkat kepribadian tangguh ditandai dengan tiga $\mathrm{C}$ yang merupakan komponen dari ketangguhan yaitu commitment, control, dan challenge.

Komponen-komponen dari ketangguhan ini akan memainkan peran dalam mengarahkan dan menjaga kesehatan individu, bahkan ketika menghadapi kejadian-kejadian yang tidak dapat dihindarkan, atau kejadian hidup yang menekan. Komitmen, kontrol, dan tantangan akan memelihara kesehatan individu meskipun berhadapan dengan kejadiankejadian yang secara umum dianggap sebagai suatu kejadian yang menimbulkan stres.

Beberapa penelitian menunjukkan bahwa ketangguhan membantu meningkatkan atau mempertahankan performa dan kesehatan ketika berada dalam kondisi stres. Penelitian ini dilakukan dalam berbagai jenis pekerjaan dan kondisi hidup (Maddi, 2006). Maddi dan Kobasa (1984) mengemukakan kembali bahwa individu yang mempunyai kepribadian ketangguhan memiliki kontrol pribadi, komitmen, dan siap dalam menghadapi tantangan, artinya perubahan-perubahan yang terjadi di dalam diri maupun di luar dirinya dilihat sebagai suatu kesempatan untuk tumbuh dan bukan sebagai suatu ancaman terhadap dirinya. Individu yang memiliki ketangguhan dianggap dapat menjaga tetap sehat meskipun mengalami kejadian-kejadian yang penuh dengan stres. Ketangguhan mempunyai serangkaian ciri atau sikap yang membuat individu tahan terhadap tekanan karena kepribadian ini menunjukkan adanya komitmen yang merupakan lawan dari alienasi, kontrol merupakan lawan ketidakberdayaan dan tantangan sebagai lawan dari takut atau situasi yang mengancam. 


\section{Gambaran Ketangguhan Ibu dalam Mengasuh Anak Autis}

Sangatlah penting untuk memahami pokok yang mendasari kepribadian tangguh. Individu yang memiliki karakteristik tangguh tidak rentan terhadap stres jika dihadapkan pada keadaan yang penuh tekanan. Kobasa (1982) telah memaparkan makna dari masing-masing komponen kepribadian tangguh, yaitu:

Pertama, komitmen. Kecenderungan untuk melibatkan diri ke dalam kegiatan apapun yang dilakukan. Kobasa (1982) menjelaskan bahwa individu yang komitmennya kuat tidak akan mudah menyerah pada tekanan, tetapi mengikuti pikiran untuk menyelesaikan tugas yang dihadapi, ia juga akan bersungguh-sungguh mengatasi tekanan yang dihadapi dalam hidupnya. Pada saat menghadapi stres individu ini akan melakukan berbagai strategi koping yang sesuai dengan nilai-nilai, tujuan dan kemampuan yang ada dalam dirinya.

Kedua, kontrol. Kontrol terdiri dari tiga aspek spesifik (kontrol pengambilan keputusan, kontrol kognitif, dan kemampuan koping). Kontrol pengambilan keputusan adalah kapasitas individu memilih di antara berbagai program tindakan untuk mengatasi stres. Kontrol kognitif adalah kemampuan untuk menginterpretasikan (menafsirkan), menilai, dan menggabungkan berbagai macam peristiwa stres menjadi rencana kehidupan yang berkelanjutan, menonaktifkan efek yang tidak menyenangkan. Kontrol kemampuan koping adalah seperangkat keterampilan yang dibutuhkan dalam merespon stres. Kontrol mengimplikasikan penggunaan inteligensi, imajinasi, keterampilan dan pilihan. Individu yang memiliki kontrol akan bertanggung jawab terhadap tujuan hidup yang telah ditetapkannya. Kontrol mencegah individu sebagai korban, tetapi bagaimana membantu individu dalam mengatasi berbagai kejadian hidup yang mengancam.

Ketiga, tantangan. Kobasa, Maddi, \& Kahn (1982) mendefinisikan tantangan sebagai sebuah keyakinan bahwa perubahan bukan stabilitas normal dalam kehidupan dan bahwa antisipasi perubahan merupakan hal menarik untuk tumbuh dibandingkan hanya sebagai ancaman keamanan. Tantangan adalah kecenderungan untuk memandang suatu perubahan dalam hidupnya sebagai sesuatu yang wajar dan dapat mengantisipasi perubahan itu sebagai stimulus yang sangat berguna bagi perkembangan dan memandang hidup sebagai suatu tantangan yang menyenangkan. 


\section{Nurussakinah Daulay}

Mengapa individu yang tangguh berbeda dengan individu lainnya?. Seseorang yang tangguh akan memiliki transformational coping. Mereka bukan menganggap diri mereka sebagai korban dari ancaman tetapi keterlibatan untuk aktif dalam menentukan arah akan perubahan mana yang akan diambil (Gentry \& Ouellette-Kobasa, 1984). Compton, Seeman, \& Norris (1991) menemukan bahwa tingginya ketangguhan berhubungan kuat dengan proses self enhancement, bahwa membantu jalannya konsep diri positif dan keyakinan yang rendah bahwa kesuksesan itu hanya karena keberuntungan. Ketika kualitas kepribadian tangguh (kontrol, komitmen, tantangan) ini diuji, jelas bahwa seseorang yang tangguh adalah seseorang yang bisa menggunakan keterampilan kognitif tertentu untuk memaknai peristiwa hidupnya dengan cara-cara yang adaptif.

Individu yang memiliki kecenderungan kepribadian tangguh yang kuat akan melakukan tindakan-tindakan yang langsung untuk mengetahui kejadian-kejadian dalam hidup dan dimasukkannya ke dalam kehidupan individu serta belajar dari kejadian-kejadian tersebut, baik nilai maupun kegunaannya. Lebih lanjut lagi individu akan melakukan tindakan yang efektif, menggunakan strategi coping yang aktif seperti problem focused coping (William, dalam Taylor, 1995).

Mengingat masih sedikitnya penelitian yang memfokuskan ketangguhan sebagai variabel dependent dan ditujukan pada ibu sebagai pengasuh utama anak autis, maka penelitian ini menarik sekali dikaji lebih lanjut untuk memperkaya ilmu pengetahuan khususnya dalam bidang psikologi positif, psikologi perkembangan, psikologi klinis dengan mengeksplorasi konsep ketangguhan pada ibu yang memiliki anak autis. Penelitian ini merupakan studi awal untuk menggambarkan konsep ketangguhan pada ibu yang memiliki anak autis. Hasil penggambaran ini juga bermanfaat bahwa dengan memiliki kepribadian tangguh akan berdampak positif pada pengasuhan ibu.

Hasil penelitian sebelumnya terkait dengan pengasuhan ibu yang memiliki anak autis juga mendukung pendapat bahwa karakteristik kepribadian tangguh dapat mengarahkan ibu untuk mengasuh anak autis lebih baik lagi. Adapun penelitian-penelitian yang pernah dilakukan di antaranya, seperti penelitian yang dilakukan oleh Weiss (2002) pada 120 ibuibu yang memiliki anak berkebutuhan khusus (40 ibu dengan anak autis, 40 ibu dengan anak mental retardasi, dan 40 ibu dengan anak yang perkembangannya normal). Penelitian 


\section{Gambaran Ketangguhan Ibu dalam Mengasuh Anak Autis}

ini menghasilkan bahwa terdapat tiga faktor dominan ibu dalam mengasuh anak berkebutuhan yaitu ketangguhan, dukungan sosial dan koping. Ketangguhan memiliki relevansi khusus sebagai variabel strategi koping sebab menggabungkan kemampuan koping dan adaptif elemen persepsi kognitif.

Penelitian di Indonesia di antaranya oleh Ambarini (2013) tentang hubungan antara ketangguhan dan tingkat stres pengasuhan ibu dengan anak autis di kota Surabaya. Hasil penelitiannya menunjukkan terdapat hubungan negatif dengan nilai korelasi $r=-0,789$, artinya semakin kuat ketangguhan yang dimiliki ibu dengan anak autis maka akan semakin rendah tingkat stres dalam pengasuhannya. Penelitian oleh Ahmad (2015) tentang Kecerdasan Emosional dan hardiness pada 70 orang ibu rumah tangga single parent. Hasilnya menunjukkan bahwa terdapat hubungan yang positif dengan nilai korelasi sebesar 0.539, artinya semakin tinggi kecerdasan emosional maka akan semakin kuat ketangguhan, serta peran kecerdasan emosional sebanyak 29\% dalam memengaruhi hardiness ibu.

Penelitian yang dilakukan oleh Rahmah (2012) untuk memperoleh gambaran mengenai pola asuh ibu suku Batak pada anak laki-laki dengan gangguan autis. Kondisi ini membuat ibu cukup stres dalam mengasuh anak autis, senada dengan penelitian yang dilakukan oleh Sitorus (2011) bahwa ibu-ibu di kota Medan memiliki nilai stres dalam kategori sedang. Berangkat dari dua penelitian pada ibu yang memiliki anak autis di kota Medan, penelitian ini penting untuk melihat sisi positif dari kepribadian ibu dalam berinteraksi dengan anak autis. Mengasuh anak autis bukan lah hal yang mudah, kompleksnya gangguan yang dialami anak autis seringkali membuat ibu mengalami kesulitan dalam mengasuh mereka, sehingga dibutuhkan kepribadian tangguh dalam mengatasi situasi yang menekan dan berdampak pada stres pengasuhan. Kesimpulannya, manfaat dari penelitian ini untuk melihat gambaran profil ketangguhan ibu dalam mengasuh anak autis di kota Medan.

\section{Metode}

Metode yang digunakan dalam penelitian ini adalah metode deskriptif yang memberikan deskripsi mengenai subjek penelitian berdasarkan data dari variabel yang diperoleh dari kelompok subjek yang diteliti dan tidak dimaksudkan untuk pengujian hipotesis (Azwar, 2012). Penelitian ini berupaya untuk melihat gambaran profil ketangguhan pada ibu yang memiliki anak autis di kota Medan dengan bantuan alat ukur 


\section{Nurussakinah Daulay}

menggunakan skala ketangguhan, kemudian juga akan dianalisa temuan seperti data demografi, aspek ketangguhan dan data tambahan lainnya agar dapat menggambarkan profil ketangguhan secara komprehensif.

Subjek penelitian berjumlah 58 orang ibu yang memiliki anak autis dan berdomisili di kota Medan Sumatera Utara. Peneliti bekerjasama dengan 2 sekolah dan 6 terapi anak autis di kota Medan, dari sekolah dan terapi tersebut didapatkan 58 orang subjek penelitian.

Tabel 2.

Karakteristik demografi pada ibu dan anak autis

\begin{tabular}{|c|c|c|c|c|c|}
\hline Variabel & Kategori & Frekuensi & Persen & Mean & SD \\
\hline \multirow[t]{4}{*}{ Usia ibu } & $20-30$ tahun & 8 & 13,7 & 46,8 & 5,6 \\
\hline & $30-40$ tahun & 31 & 53,4 & 49 & 4,4 \\
\hline & $40-50$ tahun & 18 & 31,03 & 48,2 & 5,6 \\
\hline & $>50$ tahun & 1 & 1,7 & 53 & \\
\hline \multirow[t]{6}{*}{ Suku } & Jawa & 22 & 37,9 & 49,7 & 5,3 \\
\hline & Batak & 16 & 27,5 & 48,6 & 5,1 \\
\hline & Tionghoa & 10 & 17,2 & 48,4 & 4,5 \\
\hline & Minang & 5 & 8,6 & 49 & 3,3 \\
\hline & Melayu & 4 & 6,8 & 46 & 4 \\
\hline & Bali & 1 & 1,7 & 49 & \\
\hline Status & Menikah & 50 & 86,2 & 48,8 & 4,9 \\
\hline \multirow{2}{*}{ pernikahan } & Janda (suami meninggal) & 4 & 6,8 & 51 & 3,9 \\
\hline & Janda (bercerai) & 4 & 6,8 & 47,2 & 4,7 \\
\hline \multirow[t]{2}{*}{$\begin{array}{l}\text { Hidup } \\
\text { bersama }\end{array}$} & $\begin{array}{l}\text { Hidup bersama anak, orang } \\
\text { dewasa lain }\end{array}$ & 8 & 13,7 & 49,6 & 5,01 \\
\hline & Hidup bersama anak, suami & 30 & 51,7 & 49,2 & 4,3 \\
\hline \multirow{6}{*}{$\begin{array}{l}\text { Status } \\
\text { pekerjaan }\end{array}$} & Wiraswasta & 10 & 17,2 & 48,5 & 5,3 \\
\hline & PNS & 9 & 15,5 & 49,3 & 6,1 \\
\hline & Guru & 3 & 5,1 & 52 & 7 \\
\hline & Dokter & 4 & 6,8 & 47 & 5,2 \\
\hline & Pegawai swasta & 4 & 6,8 & 51,5 & 3,5 \\
\hline & Ibu rumah tangga & 28 & 48,2 & 48,4 & 4,1 \\
\hline \multirow[t]{4}{*}{ Pendidikan } & Tamatan SD & 0 & 0 & 0 & 0 \\
\hline & Tamatan SMP & 0 & 0 & 0 & 0 \\
\hline & Tamatan SMA & 7 & 12,06 & 47,3 & 3,9 \\
\hline & Tamatan S1 & 51 & 87,9 & 49,1 & 4,9 \\
\hline \multirow[t]{4}{*}{ Jumlah anak } & 1 & 11 & 18,9 & 48,9 & 3,8 \\
\hline & 2 & 25 & 43,1 & 48,8 & 5,7 \\
\hline & 3 & 16 & 27,5 & 49,8 & 4,01 \\
\hline & $>3$ & 6 & 10,3 & 47,8 & 4,8 \\
\hline
\end{tabular}




\section{Gambaran Ketangguhan Ibu dalam Mengasuh Anak Autis}

\begin{tabular}{|c|c|c|c|c|c|}
\hline \multirow[t]{5}{*}{ Pendapatan } & < Rp. 1.000 .000 & 1 & 1,7 & 50 & \\
\hline & Rp. 1.000 .000 - Rp. 2.000 .000 & 8 & 13,7 & 47,5 & 6,02 \\
\hline & Rp. 2.000 .000 - Rp. 3.000 .000 & 9 & 15,5 & 47,8 & 4,8 \\
\hline & Rp. 3.000 .000 - Rp 4.000 .000 & 16 & 27,5 & 50,4 & 3,7 \\
\hline & $>$ Rp. 4.000 .000 & 24 & 41,3 & 48,6 & 5,1 \\
\hline \multirow[t]{3}{*}{ Jenis autis } & Autis mild & 36 & 63,8 & 48,9 & 4,4 \\
\hline & Autis moderate & 17 & 27,5 & 48,9 & 5,7 \\
\hline & Autis severe & 5 & 8,6 & 48,2 & 5,4 \\
\hline \multirow[t]{4}{*}{ Usia anak } & $2-5$ tahun & 9 & 15,5 & 45,7 & 4,4 \\
\hline & 5-10 tahun & 31 & 53,4 & 49,1 & 3,8 \\
\hline & 10-15 tahun & 12 & 22,4 & 50,5 & 6,2 \\
\hline & 15-20 tahun & 6 & 8,6 & 48,8 & 5,9 \\
\hline \multirow{3}{*}{$\begin{array}{l}\text { Jenis } \\
\text { anak }\end{array}$} & Laki-laki & 46 & 79,3 & 49,3 & 4,8 \\
\hline & Perempuan & 12 & 20,6 & 47 & 4,5 \\
\hline & Jumlah & 58 & $100 \%$ & & \\
\hline
\end{tabular}

Pengumpulan data menggunakan alat ukur skala ketangguhan (Dispositional Resilience Scale/DRS-15) versi pendek yang dikembangkan oleh Bartone (1995). Pada awal tahun 1980, skala ini awalnya digunakan oleh Maddi dan Kobasa yang terdiri atas 53 item, kemudian direvisi oleh Bartone menjadi 15 item (Bartone, 1995). Perbaikan ini dimaksudkan untuk menghasilkan "indikator positif ketangguhan" (Bartone, 1991). Hal inilah yang menjadi alasan peneliti menggunakan skala ketangguhan dari Bartone, yaitu Bartone telah mengadaptasi skala ketangguhan ini dari Maddi \& Kobasa dan merevisi kembali menjadi versi pendek sebanyak 15 item, namun tetap tidak mengubah makna aspek-aspek ketangguhan dari Maddi dan Kobasa yang di awal terdiri atas 53 item.

DRS-15 adalah instrumen yang terdiri atas 15 item dan mencakup item-item secara positif dan negatif mengukur tiga dimensi dari komitmen, kontrol dan tantangan (Bartone, 1995). Untuk aspek komitmen terdiri atas 5 item (4 item positif dan 1 item negatif), untuk aspek kontrol juga terdiri atas 5 item (4 item positif dan 1 item negatif), dan terakhir aspek tantangan terdiri dari 5 item ( 2 item positif dan 3 item negatif). DRS-15 ini telah diperkenalkan dengan koefisien alpha 0.83 untuk total skala, 0.77 untuk komitmen, 0.71 untuk kontrol, dan 0.70 untuk dimensi tantangan (Bartone, 1995). Setiap jawaban memiliki skor yang berbeda, pada pernyataan positif jawaban sangat tidak benar diberi nilai 1, sedikit benar diberi nilai 2, cukup benar diberi nilai 3, dan sepenuhnya benar diberi nilai 4 . Untuk pernyataan negatif, penilaiannya berkebalikan dengan pernyataan positif. Skor subjek didapat dengan menjumlahkan pilihan jawabannya. 


\section{Nurussakinah Daulay}

Hasil

Hasil skoring pada 58 subjek yang mengisi Skala Ketangguhan Ibu, diperoleh data yang akan dipaparkan dalam Tabel 3:

Tabel 3.

Statistik deskriptif

\begin{tabular}{ccccccccccc}
\hline \multicolumn{1}{c}{ Hipotetik } & \multicolumn{1}{c}{ Empirik } \\
\hline & N & Min & Max & Mean & SD & N & Min & Max & Mean & SD \\
\hline Total & 58 & 15 & 30 & 22.5 & 7.5 & 58 & 35 & 57 & 48.8 & 4.84 \\
\hline
\end{tabular}

Berdasarkan hasil data pada Tabel 3 dapat disimpulkan bahwa pada variabel ketangguhan mempunyai mean hipotetik lebih rendah dari mean empirik. Hal ini menunjukkan bahwa ketangguhan subjek penelitian cenderung tinggi. Kemudian, skor SD yang diperoleh pada variabel penelitian terlihat bahwa skor SD hipotetik lebih besar daripada SD empiriknya. Hal ini dapat diartikan bahwa skor yang diperoleh subjek terlihat jauh berbeda atau dapat dikatakan cenderung setara.

Deskripsi data ini memungkinkan peneliti untuk melakukan kategorisasi dengan mengacu pada kriteria kategorisasi 3 kelompok oleh Azwar (2012), yaitu rendah, sedang dan tinggi. Tujuan dari kategorisasi ini untuk menempatkan subjek ke dalam kelompokkelompok yang posisinya berjenjang menurut suatu norma kategori yang telah ada dan agar data akan lebih mudah dipahami (Azwar, 2012).

Tabel 4.

Kategorisasi ketangguhan ibu

\begin{tabular}{ccc}
\hline Kategori & Jumlah & Persentase \\
\hline Rendah & 6 & 10,3 \\
Sedang & 43 & 74,1 \\
Tinggi & 9 & 15,5 \\
\hline
\end{tabular}

Berdasarkan Tabel 4 di atas menunjukkan bahwa dari 58 subjek dalam penelitian ini, mayoritas para ibu memiliki tingkat ketangguhan dalam kategori sedang, lalu diikuti dengan tingkat ketangguhan pada kategori tinggi dan kategori rendah.

\section{Aspek Komitmen}

Tabel 5 berikut ini menunjukkan bahwa jika ditinjau dari aspek komitmen, mayoritas ibu memiliki tingkat komitmen dalam kategori sedang, kemudian diikuti oleh ibu dengan tingkat komitmen pada kategori tinggi dan rendah. 


\section{Gambaran Ketangguhan Ibu dalam Mengasuh Anak Autis}

Tabel 5 .

Ketangguhan ibu aspek komitmen

\begin{tabular}{ccc}
\hline Kategori & Jumlah & Persentase \\
\hline Rendah & 6 & 10,3 \\
Sedang & 45 & 77,5 \\
Tinggi & 7 & 12,06 \\
\hline
\end{tabular}

\section{Aspek Kontrol}

Hasil pada Tabel 6 menunjukkan bahwa jika ditinjau dari aspek kontrol, mayoritas ibu memiliki tingkat kontrol dalam kategori sedang, kemudian diikuti oleh kelompok ibu dengan kategori kontrol tinggi dan rendah.

Tabel 6.

Ketangguhan ibu aspek kontrol

\begin{tabular}{ccc} 
Kategori & Jumlah & Persentase \\
\hline Rendah & 8 & 13,7 \\
Sedang & 37 & 63,7 \\
Tinggi & 13 & 22,4 \\
\hline
\end{tabular}

\section{Aspek Tantangan}

Tabel 7 menunjukkan hasil ketangguhan ibu ditinjau dari aspek tantangan. Mayoritas ibu memiliki tingkat tantangan dalam kategori sedang, kemudian diikuti pada ibu dengan kategori tantangan tinggi dan ibu dalam kategori tantangan yang rendah.

Tabel 7.

Ketangguhan ibu aspek tantangan

\begin{tabular}{lll}
\hline \multicolumn{1}{c}{ Kategori } & Jumlah & Persentase \\
\hline Rendah & 14 & 24,1 \\
Sedang & 23 & 39,6 \\
Tinggi & 21 & 36,2 \\
\hline
\end{tabular}

Tabel 8.

Statistik deskriptif aspek ketangguhan

\begin{tabular}{lrrrrr}
\hline & N & Minimum & Maximum & Mean & Std. Deviation \\
\hline Komitmen & 58 & 10 & 20 & 17.59 & 2.026 \\
Kontrol & 58 & 9 & 20 & 16.97 & 2.192 \\
Tantangan & 58 & 7 & 18 & 14.33 & 2.481 \\
Valid N (listwise) & 58 & & & & \\
\hline
\end{tabular}




\section{Nurussakinah Daulay}

Tabel 8 menunjukkan bahwa aspek komitmen memiliki nilai mean yang tertinggi, kemudian diikuti dengan aspek kontrol dan aspek tantangan.

Tabel 9.

Reliability statistics

\begin{tabular}{cc}
\hline Cronbach's Alpha & N of Items \\
\hline 0,676 & 15 \\
\hline
\end{tabular}

Penelitian ini juga menghasilkan reliabilitas alat ukur dengan menggunakan teknik Alpha Cronbach dan dibantu dengan program SPSS version 21.0 for Windows. Nilai koefisien alpha yang diperoleh ialah 0,676. Nilai ini cukup rendah, sebab kriteria level untuk instrumen pengukuran afektif (seperti ketangguhan) nilai minimum reliabilitas adalah 0,70 (Gable, et al , 1993). Menurut peneliti salah satu faktor yang menyebabkan nilai reliabilitas rendah adalah alat ukur yang digunakan (Dispositional Resilience Scale/DRS-15) adalah alat ukur yang peneliti adaptasi dari Bartone (1995) dengan subjek penelitian yang berbeda dan dengan budaya yang berbeda pula. Bartone menggunakan alat ukur ini pada pasukan khusus angkatan darat dan pasukan di perang teluk, sedangkan peneliti menggunakannya pada ibu-ibu yang memiliki anak autis. Kemudian peneliti mencoba merevisi dengan membuang 6 item yang merupakan nilai terendah, sehingga untuk aspek kontrol $(2,6,8,9,15)$ item yang dibuang adalah 6 dan 9, untuk aspek komitmen $(1,4,7,10,12)$ item yang dibuang adalah 4 dan 7 , untuk aspek tantangan $(3,5,11,13,14)$ item yang dibuang adalah 3 dan 14, sehingga didapati nilai koefisien alpha yang terbaru yaitu 0,710. Disarankan untuk penelitian yang serupa dengan menggunakan alat ukur Dispositional Resilience Scale/DRS-15 dan subjek yang serupa pula, maka perlu diperhatikan nilai reliabilitasnya dan item yang akan digunakan. Nilai reliabilitas terbaru adalah 0,710 dianggap sudah cukup reliabel dengan membuang 6 item dari 15 item yang ada.

Tabel 10.

Reliability Statistics

\begin{tabular}{cl}
\hline Cronbach's Alpha & N of Items \\
\hline 0,710 & 9 \\
\hline
\end{tabular}

Hasil penelitian ini diperkaya dengan adanya analisis lanjutan terkait karakteristik subjek penelitian, yaitu usia ibu, suku bangsa, pekerjaan, status pernikahan, pendapatan keluarga, tingkat pendidikan, hidup bersama dengan, jumlah anak, usia anak, jenis kelamin anak, dan diagnosa autis pada anak. 


\section{Gambaran Ketangguhan Ibu dalam Mengasuh Anak Autis}

Tabel 11.

Statistik deskriptif usia ibu

\begin{tabular}{lrrrrr}
\hline & N & Minimum & Maximum & Mean & Std. Deviation \\
\hline Usia 20 & 8 & 37 & 53 & 46.88 & 5.643 \\
Usia 30 & 31 & 37 & 56 & 49.00 & 4.412 \\
Usia 40 & 18 & 35 & 57 & 48.22 & 5.683 \\
Usia 60 & 1 & 53 & 53 & 53.00 &. \\
Valid N (listwise) & 1 & & & & \\
\hline
\end{tabular}

Berdasarkan usia ibu, ibu dalam kategori usia $>50$ tahun memiliki mean ketangguhan yang lebih tinggi dibandingkan dengan mean ketangguhan Ibu dalam kategori usia 30-40 tahun, dan usia 40-50 tahun serta kategori usia 20-30 tahun.

Tabel 12.

Statistik deskriptif suku bangsa ibu

\begin{tabular}{lrrrrr}
\hline & N & Minimum & Maximum & Mean & Std. Deviation \\
\hline Jawa & 22 & 37 & 57 & 49.73 & 5.391 \\
Batak & 16 & 35 & 56 & 48.69 & 5.134 \\
Tionghoa & 10 & 43 & 57 & 48.40 & 4.526 \\
Minang & 5 & 44 & 53 & 49.00 & 3.391 \\
Melayu & 4 & 40 & 49 & 46.00 & 4.082 \\
Bali & 1 & 49 & 49 & 49.00 &. \\
Valid N (listwise) & 1 & & & & \\
\hline
\end{tabular}

Berdasarkan suku bangsa, ibu bersuku Jawa memiliki mean ketangguhan yang paling tinggi, kemudian diikuti dengan ibu bersuku Minang, ibu bersuku Bali, ibu bersuku Batak, ibu bersuku Tionghoa, dan yang terakhir ibu bersuku Melayu.

Tabel 13.

Statistik deskriptif pekerjaan ibu

\begin{tabular}{lrrrrr}
\hline & N & Minimum & Maximum & Mean & Std. Deviation \\
\hline wiraswasta & 10 & 40 & 56 & 48.50 & 5.359 \\
PNS & 9 & 35 & 56 & 49.33 & 6.185 \\
guru & 3 & 44 & 57 & 52.00 & 7.000 \\
dokter & 4 & 40 & 52 & 47.00 & 5.292 \\
Peg. swasta & 4 & 48 & 55 & 51.50 & 3.512 \\
IRT & 28 & 37 & 57 & 48.43 & 4.194 \\
Valid N (listwise) & 3 & & & & \\
\hline
\end{tabular}

Berdasarkan pekerjaan, ibu yang bekerja sebagai guru memiliki mean ketangguhan paling tinggi, kemudian diikuti ibu yang bekerja sebagai pegawai swasta, ibu yang bekerja sebagai PNS, ibu yang bekerja sebagai wiraswasta, berperan sebagai ibu rumah tangga, dan pekerjaan ibu yang memiliki mean paling rendah ialah ibu yang bekerja sebagai dokter. 


\section{Nurussakinah Daulay}

Tabel 14.

Statistik deskriptif status pernikahan ibu

\begin{tabular}{lrrrrr}
\hline & N & Minimum & Maximum & Mean & Std. Deviation \\
\hline Menikah & 50 & 35 & 57 & 48.84 & 4.938 \\
Janda & 4 & 46 & 55 & 51.00 & 3.916 \\
Bercerai & 4 & 43 & 54 & 47.25 & 4.787 \\
Valid N (listwise) & 4 & & & & \\
\hline
\end{tabular}

Berdasarkan status pernikahan, ibu yang berstatus janda karena suaminya meninggal memiliki mean ketangguhan yang paling tinggi, kemudian diikuti pada ibu yang menikah, dan ibu yang berstatus janda karena bercerai dari suaminya memiliki mean ketangguhan yang paling rendah.

Tabel 15.

Statistik deskriptif pendapatan ibu perbulan

\begin{tabular}{lrrrrr}
\hline & N & Minimum & Maximum & Mean & Std. Deviation \\
\hline$<1$ jt. & 1 & 50 & 50 & 50.00 &. \\
$1-2$ jt. & 8 & 37 & 57 & 47.50 & 6.024 \\
$2-3$ jt. & 9 & 41 & 55 & 47.89 & 4.859 \\
$3-4$ jt. & 16 & 45 & 57 & 50.44 & 3.723 \\
$>4$ jt. & 24 & 35 & 56 & 48.63 & 5.199 \\
Valid N (listwise) & 1 & & & & \\
\hline
\end{tabular}

Berdasarkan pendapatan keluarga, ibu dengan pendapatan Rp.3.000.000 sampai Rp. 4.000.000 memiliki mean ketangguhan yang paling tinggi, kemudian ketangguhan sedang terdapat pada ibu yang berpenghasilan di bawah Rp.1.000.000, Ibu yang berpendapatan di atas Rp.4.000.000, lalu ibu dengan pendapatan antara Rp. 1.000.000 sampai Rp. 3.000.000.

Tabel 16.

Statistik deskriptif jenjang pendidikan ibu

\begin{tabular}{lrrrrr}
\hline & N & Minimum & Maximum & Mean & Std. Deviation \\
\hline SMA & 7 & 41 & 53 & 47.29 & 3.904 \\
S1 & 51 & 35 & 57 & 49.10 & 4.953 \\
Valid N (listwise) & 7 & & & & \\
\hline
\end{tabular}

Berdasarkan pendidikan, ibu yang mengenyam pendidikan sampai jenjang perkuliahan Strata Satu memiliki mean ketangguhan yang lebih tinggi dibandingkan ibu yang mengenyam pendidikan sampai Sekolah Menengah Atas. 


\section{Gambaran Ketangguhan Ibu dalam Mengasuh Anak Autis}

Tabel 17.

Statistik deskriptif ibu hidup bersama dengan

\begin{tabular}{lrrrrr}
\hline & \multicolumn{1}{c}{ N } & Minimum & Maximum & Mean & Std. Deviation \\
\hline Anak orang dewasa & 8 & 40 & 55 & 49.63 & 5.012 \\
Anak suami & 30 & 41 & 57 & 49.27 & 4.362 \\
Anak suami orang & 20 & 35 & 56 & 48.00 & 5.554 \\
dewasa & & & & & \\
Valid N (listwise) & 8 & & & & \\
\hline
\end{tabular}

Berdasarkan hidup bersama maka ibu yang hidup bersama dengan anak, suami saja serta ibu yang hidup bersama anak, dan terdapat orang dewasa lain tanpa adanya suami, memiliki nilai mean ketangguhan yang sama besarnya, kemudian diikuti dengan ibu yang hidup bersama anak, suami, dan orang dewasa lainnya.

Tabel 18.

Statistik deskriptif jumlah anak

\begin{tabular}{lrrrrr}
\hline & N & Minimum & Maximum & Mean & Std. Deviation \\
\hline satu & 11 & 40 & 54 & 48.09 & 3.885 \\
dua & 25 & 35 & 57 & 48.84 & 5.764 \\
tiga & 16 & 43 & 57 & 49.88 & 4.015 \\
Lebih dari tiga & 6 & 41 & 55 & 47.83 & 4.875 \\
Valid N (listwise) & 6 & & & & \\
\hline
\end{tabular}

Berdasarkan jumlah anak yang dimiliki ibu, ibu dengan jumlah anak tiga memiliki mean ketangguhan lebih tinggi, kemudian diikuti dengan ibu yang memiliki anak satu dan dua, dan terakhir ibu yang memiliki anak lebih dari tiga.

Berdasarkan jenis diagnosa autis pada anak, ibu yang memiliki anak autis mild, dan moderate memiliki mean ketangguhan paling tinggi, kemudian diikuti dengan ibu yang memiliki anak autis severe (Tabel 19).

Tabel 19.

Statistik deskriptif jenis autis pada anak

\begin{tabular}{lrrrrr}
\hline & N & Minimum & Maximum & Mean & Std. Deviation \\
\hline mild & 36 & 37 & 57 & 48.94 & 4.446 \\
moderate & 17 & 35 & 57 & 48.94 & 5.739 \\
severe & 5 & 40 & 55 & 48.20 & 5.404 \\
Valid N (listwise) & 5 & & & & \\
\hline
\end{tabular}




\section{Nurussakinah Daulay}

Tabel 20.

Statistik deskriptif usia anak

\begin{tabular}{lrrrrr}
\hline & N & Minimum & Maximum & Mean & Std. Deviation \\
\hline limatahun & 9 & 37 & 50 & 45.78 & 4.438 \\
sepuluhtahun & 31 & 40 & 57 & 49.13 & 3.879 \\
limabelas & 12 & 35 & 57 & 50.58 & 6.259 \\
duapuluh & 6 & 41 & 56 & 48.83 & 5.913 \\
Valid N (listwise) & 6 & & & & \\
\hline
\end{tabular}

Berdasarkan usia anak, ibu yang memiliki anak autis dalam kategori berusia 15-20 tahun memiliki mean ketangguhan yang lebih tinggi, kemudian diikuti dari kategori usia anak 5-10 tahun, kemudian mean ketangguhan dari ibu yang memiliki anak autis dalam kategori usia anak dua puluh tahun ke atas, dan terakhir ibu dengan mean ketangguhan yang paling rendah adalah ibu yang memiliki anak autis dengan kategori usia 2-5 tahun.

Tabel 21.

Statistik deskriptif jenis kelamin anak

\begin{tabular}{lrrrrr}
\hline & N & Minimum & Maximum & Mean & Std. Deviation \\
\hline pria & 46 & 37 & 57 & 49.37 & 4.850 \\
wanita & 12 & 35 & 54 & 47.00 & 4.533 \\
Valid N (listwise) & 12 & & & & \\
\hline
\end{tabular}

Berdasarkan jenis kelamin anak, ibu yang memiliki anak laki-laki memiliki nilai mean ketangguhan yang paling tinggi dibandingkan mean ketangguhan dari kategori ibu yang memiliki anak autis dengan berjenis kelamin perempuan.

\section{Diskusi}

Hasil penelitian ini, menunjukkan bahwa mayoritas ibu dengan anak autis di kota Medan memiliki ketangguhan dalam kategori sedang. Ibu yang memiliki kategori ketangguhan sedang berarti bahwa ibu memiliki kepribadian tangguh pada dirinya dengan menerima kondisi keterbatasan anaknya, dan mengasuhnya dengan usaha dan kasih sayang. Ibu merawat serta mengasuh anak meskipun ibu terkadang tetap merasakan emosiemosi negatif dalam dirinya seperti terkadang merasa sedih akan nasib masa depan anaknya, sedikit repot mengurus anak, tidak memiliki banyak waktu luang untuk diri sendiri, dan banyaknya biaya yang harus disediakan dalam perawatan anak autis.

Ibu yang memiliki level ketangguhan tinggi berarti ibu telah ikhlas menerima kondisi keterbatasan anaknya, menyikapi dengan bijak permasalahan dalam kehidupan, terus 


\section{Gambaran Ketangguhan Ibu dalam Mengasuh Anak Autis}

berjuang untuk masa depan anak, yakin dengan kekuasaan Allah akan membantu ibu. Bagi ibu memiliki anak autis merupakan cobaan yang diberikan Tuhan kepada keluarganya karena menganggap bahwa Ibu adalah individu terpilih yang kuat dalam mengasuh dan menyayangi anak autis, ibu ikhlas menerima jalan hidup yang Tuhan berikan dengan mengkaruniai anak yang hebat seperti anak autis, kemudian berupaya memberikan yang terbaik bagi kehidupan anak, ada ketabahan dan keyakinan bahwa semua masalah akan terdapat jalan keluarnya, dengan selalu berusaha dan berdoa. Hal ini juga diperkuat dengan hasil analisa berdasarkan karakteristik subjek penelitian, misalnya berdasarkan usia ibu, ibu dalam kategori usia > 50 tahun memiliki mean ketangguhan yang lebih tinggi, artinya semakin bertambahnya usia maka meningkat pula kemampuan dalam memaknai kehidupan, setiap permasalahan yang terjadi khususnya terkait permasalahan anak autis dianggap sebagai ujian dari Tuhan. Santrock (2002) menjelaskan bahwa pada masa dewasa lanjut menyelesaikan permasalahan-permasalahan praktis dengan cara yang bijak. Ibu-ibu yang menginjak usia dewasa akhir akan menjadi lebih bijak dalam memahami permasalahan yang menyangkut kebutuhan anak autis.

Hasil penelitian tambahan terkait suku bangsa ibu menunjukkan ibu bersuku Jawa memiliki mean ketangguhan yang paling tinggi kemudian diikuti ibu bersuku Minang, Bali, Batak, Tionghoa dan Melayu. Bagi masyarakat yang bersuku Jawa sendiri terdapat konsep narima ing pandum (NIP) yang merupakan salah satu nilai budaya yang dikenal dan diadopsi (Endraswara, 2012). Menurut Koentjaraningrat (1990), sikap narima ing pandum yang berkaitan erat dengan aspek spiritual telah melahirkan sebuah nilai fundamental dan tidak lekang ditelan jaman. Narima ing pandum (NIP) adalah sebuah sikap penerimaan secara penuh terhadap berbagai kejadian pada masa lalu, masa sekarang serta segala kemungkinan yang bisa terjadi pada masa yang akan datang. Hal ini merupakan upaya untuk mengurangi kekecewaan apabila yang terjadi kemudian ternyata tidak sesuai dengan apa yang diharapkan (Endraswara, 2012). Sikap narima ing pandum menjadi ciri yang cukup kuat pada pribadi individu dengan latar belakang budaya Jawa (Martiarini, 2012).

Hasil penelitian tambahan terkait pekerjaan ibu juga diperoleh mean ketangguhan ibu yang bekerja sebagai guru lebih tinggi dibanding ibu dengan pekerjaan PNS, Pegawai Swasta, wiraswasta, dokter, dan yang tidak bekerja hanya sebagai ibu rumah tangga. Pekerjaan dapat menimbulkan stres bagi individu jika tidak memiliki kepribadian positif dalam dirinya. Beberapa penelitian melaporkan tingkat stres yang tinggi pada level pekerjaan stres dan rendahnya sumber koping (Edwards, 1988; Karasek \& Theorell, 1990; 


\section{Nurussakinah Daulay}

Osipow \& Davis, 1988, Osipow \& Spokane, 1987, dalam Judkins, 2001). Guru merupakan profesi yang syarat dengan ilmu pengetahuan dan terbiasa berkomunikasi dan berhubungan dengan peserta didik. Ini merupakan kelebihan dari profesi seorang guru, sehingga membentuk kepribadian positif dalam mendidik siswanya. Ibu yang berprofesi sebagai guru biasanya tidak canggung dalam mengasuh anak autis, sebab selain terbiasa mengajarkan keterampilan belajar pada anak-anak, ibu juga mengajarkan menanamkan kelebihan dari masing-masing individu, sehingga ini menjadi salah satu alasan ibu yang berprofesi sebagai guru lebih menerima kondisi anak autis dan menjadikannya tangguh dalam merawat anak.

Hasil penelitian tambahan terkait status pernikahan ibu juga diperoleh mean ketangguhan ibu yang berstatus janda karena suaminya meninggal lebih tinggi nilainya dibanding ibu yang suaminya masih ada ataupun ibu yang berstatus janda karena bercerai. Santrock (2002) mengungkapkan bahwa banyak orang dewasa yang hidup sendiri menyebut kebebasan pribadi sebagai salah satu keuntungan pokok mereka. Perempuan dewasa merasakan kebebasan tanpa campur tangan orang lain. Hal ini juga yang memengaruhi ibu menjadi lebih tangguh karena ibu harus mencukupi kebutuhan keluarganya sendiri.

Hasil penelitian tambahan terkait pendapatan ibu juga diperoleh mean ketangguhan ibu yang berpenghasilan di bawah Rp. 1.000 .000 memiliki nilai yang paling tinggi. Beberapa penelitian melaporkan tingkat stres yang tinggi pada level pekerjaan stres dan rendahnya sumber koping (Edwards, 1988; Karasek \& Theorell, 1990; Osipow \& Davis, 1988, Osipow \& Spokane, 1987, dalam Judkins, 2001). Pendapatan di bawah Rp. 1,000,000 merupakan pendapatan yang sangat rendah untuk mencukupi kebutuhan keluarga, diperlukan keuletan dan ketangguhan dalam hal ini dapat dianggap sebagai sumber koping dalam bekerja. Hal ini pula yang memengaruhi ibu untuk tetap tangguh tidak hanya dalam pekerjaan namun juga tangguh dalam merawat anak autis.

Hasil penelitian tambahan terkait pendidikan ibu juga diperoleh mean ketangguhan ibu yang berpendidikan sampai strata satu memiliki nilai lebih tinggi dibanding ibu yang hanya berpendidikan sampai SMA. Ibu yang mengenyam pendidikan lebih tinggi akan berkorelasi positif terhadap kemampuan berpikir dan kemampuan menyikapi permasalahan keluarga khususnya terkait permasalahan yang berhubungan dengan anak autis.

Hasil penelitian tambahan terkait jenis autis yang ada pada anak, maka diperoleh mean ketangguhan yang sama besarnya pada ibu yang memiliki anak autis mild, moderate, 


\section{Gambaran Ketangguhan Ibu dalam Mengasuh Anak Autis}

dan severe, artinya ibu yang memiliki anak autis tidak membandingkan tingkat keparahan anak, intinya ibu yang memiliki anak autis harus memiliki kepribadian tangguh, kesabaran, sikap pantang menyerah, agar anak tumbuh kembangnya juga menjadi optimal.

Hasil penelitian tambahan terkait usia anak autis, diperoleh mean ketangguhan yang paling tinggi pada ibu dengan anak autis berusia 10-15 tahun. Usia 10-15 tahun merupakan usia pada masa remaja yang dipandang sebagai suatu masa yang di awali dengan datangnya masa pubertas dan berakhir dengan datangnya kedewasaan. Pubertas merupakan proses kematangan seksual dan kemampuan reproduksi serta berdampak pada keinginan untuk menjalin hubungan dekat dengan lawan jenis. Pengasuhan ekstra ibu yang memiliki anak autis terus terjadi sepanjang kehidupan anak, meskipun anak sudah tumbuh remaja bukan berarti masalah akan selesai. Pada masa remaja ini, ibu akan menemukan masalah-masalah baru lagi berupa keinginan anak autis untuk menyalurkan hasrat seksualnya, rendahnya kemampuan kognitif anak untuk mengontrol perilakunya sendiri yang akhirnya membuat ibu menjadi lebih tangguh dalam merawatnya. Maulana (2014) menjelaskan pada usia 2-5 tahun, anak autis cenderung memiliki kebiasaan yang sangat buruk, tetapi tatkala menginjak usia 6-10 tahun, perilaku mereka akan membaik. Tetapi, perilaku ini akan cenderung memburuk kembali saat anak memasuki usia remaja serta dewasa, dan selanjutnya akan kembali membaik seiring dengan bertambah tuanya usia mereka.

Hasil penelitian tambahan terkait jenis kelamin anak, diperoleh mean ketangguhan yang paling tinggi pada ibu dengan anak autis berjenis kelamin laki-laki. Penelitian yang dilakukan oleh Fombonne (2005) menjelaskan bahwa prevalensi autis lebih banyak pada laki-laki dibandingkan wanita berkisar 4:1. Pada anak autis laki-laki menunjukkan masalah perilaku lebih "externalizing" (perilaku berdampak pada lingkungan eksternal) dibandingkan wanita, seperti masalah dalam perilaku agresi, hiperaktif, penurunan perilaku pro sosial dan peningkatan perilaku dan minat yang berulang/terbatas (Bolte, et al , 2011). Dengan demikian, perilaku yang ditampilkan anak autis laki-laki membuat ibu harus lebih intens dalam mengobservasi perilaku dan menjadi lebih tangguh dalam merawat anaknya.

Ibu yang memiliki kategori ketangguhan rendah adalah ibu yang selama pengasuhan dan memiliki anak autis masih mendominasi emosi-emosi negatif dalam dirinya, sehingga dalam proses pengasuhan anak, ibu tampil dalam bentuk perilaku yang kurang optimal. Ibu masih merasakan stres, lekas marah, tersinggung, sedih dan terkadang belum bisa menerima kondisi anak. Ibu merasa lemah dalam menghadapi cobaan yang diberikan, sering mengeluh dan capek dalam merawat anak, masih sering marah juga dengan perilaku 


\section{Nurussakinah Daulay}

anak autis yang membingungkan orang tua (seperti tantrum), terkadang membandingkan kondisi tumbuh kembang anaknya dengan kondisi anak yang normal.

Berdasarkan nilai mean yang diperoleh dari setiap aspek ketangguhan, yaitu mean aspek komitmen sebesar 17.59, mean aspek kontrol sebesar 16.97, dan mean aspek tantangan sebesar 14.33, diketahui bahwa ketangguhan dari aspek komitmen memiliki nilai mean yang tertinggi. Hal ini berarti bahwa ketangguhan yang dimiliki ibu dengan anak autis termanifestasi paling besar terhadap aspek komitmen. Ibu memiliki komitmen kuat dan tidak akan mudah menyerah pada tekanan yang dihadapi terkait dengan kondisi emosi, kognisi, dan perilaku anak autis. Komitmen merupakan salah satu yang mendasari kepribadian tangguh, didefinisikan Kobasa (1982) sebagai kecenderungan untuk melibatkan diri ke dalam kegiatan apapun yang dilakukan. Individu yang mempunyai komitmen yang kuat akan mudah tertarik dan terlibat secara tulus ke dalam kegiatan apapun yang sedang dikerjakan dan perasaan yang wajar akan menuntunnya untuk mengidentifikasikan dan memberikan arti pada setiap kejadian dan segala sesuatu yang ada dalam lingkungannya. Jadi ibu yang komitmennya kuat akan mampu menghadapi stres dan melakukan berbagai koping yang sesuai dengan nilai-nilai, tujuan dan kemampuan yang ada dalam dirinya. Koping dipandang sebagai faktor penyeimbang usaha individu untuk mempertahankan penyesuaian dirinya selama menghadapi situasi yang dapat menimbulkan stres (Billing \& Moos, 1984).

Berdasarkan nilai mean yang diperoleh dari setiap aspek ketangguhan, yaitu mean aspek kontrol sebesar 16.97, yang artinya kecenderungan untuk menerima dan percaya bahwa ibu dapat mengontrol dan memengaruhi kejadian dengan pengalamannya ketika berhadapan dengan hal-hal yang tidak terduga. Memiliki anak autis merupakan peristiwa hidup yang tidak terduga dan siapapun tidak dapat menolak ketentuan Tuhan. Awalnya cukup sulit bagi ibu untuk menerima kondisi anak, namun karena adanya dukungan sosial dari suami dan keluarga besar, serta faktor pemahaman religiusitas yang cukup baik dengan menganggap bahwa kehadiran anak autis merupakan cobaan dan anugerah dari Tuhan, dan berkeyakinan menggantikan konsep cobaan itu menjadi amal ibadah, merawat anak autis menjadikan ibu memiliki gudang amal ibadah yang akan ibu terima nanti di hari kemudian. Sehingga ini memotivasi ibu untuk mengontrol perilaku dalam mengasuh anak autis menjadi terasa lebih ringan dan bukan sebagai beban. Ibu yang memiliki kontrol kuat akan selalu lebih optimis dalam menghadapi masalah-masalah dibandingkan ibu yang memiliki kontrol rendah.

Berdasarkan nilai mean yang diperoleh dari setiap aspek ketangguhan, yaitu mean aspek tantangan sebesar 14.33. Tantangan adalah kecenderungan untuk memandang suatu 


\section{Gambaran Ketangguhan Ibu dalam Mengasuh Anak Autis}

perubahan dalam hidupnya sebagai sesuatu yang wajar dan dapat mengantisipasi perubahan itu sebagai stimulus yang sangat berguna bagi perkembangan dan memandang hidup sebagai suatu tantangan yang menyenangkan (Kobasa, 1982). Individu yang mempunyai tantangan yang kuat adalah orang-orang yang dinamis dan memiliki kemampuan dan keinginan untuk maju yang kuat, menemukan cara yang lebih mudah untuk menghilangkan atau mengurangi keadaan yang menimbulkan stres dan menganggap stres bukan sebagai hambatan (Strutton, Pelton, \& Lumpkin, 1995). Dalam penelitian ini, berdasarkan mean ketangguhan aspek tantangan, ibu memiliki nilai tantangan yang cukup baik. Ibu tidak ingin berlarut-larut dalam kesedihan dengan melihat kondisi keterbatasan anaknya, ibu berusaha dengan membawa anak kepada orang-orang profesional seperti dokter, psikolog, terapis serta memasukkan anaknya ke sekolah-sekolah ataupun ke tempat terapis autis agar anak memiliki tumbuh kembang yang lebih baik. Keinginan dan harapan agar anaknya memiliki tumbuh kembang yang lebih baik, membuat ibu bersemangat, berpikir positif, tidak mudah menyerah, bersabar, terus berusaha dan berdoa.

Pada aspek tantangan ini, ibu juga berusaha dengan mencari informasi mengenai tumbuh kembang anak autis, tidak hanya terfokus oleh diagnosa dokter ataupun psikolog, tetapi ibu juga belajar sendiri dengan membaca informasi tentang anak autis bersumber dari buku, internet, informasi dari komunitas ibu yang memiliki anak autis juga. Ibu juga berusaha untuk memahami profil tentang kekuatan dan kelemahan anaknya sendiri. Profil dapat berasal dari kognisi, emosi dan perilaku anak. Hal ini bukanlah tugas yang mudah bagi ibu, butuh dukungan dari suami dan keluarga untuk lebih intens mengobservasi anak. Sastry \& Aguirre, (2012) menjelaskan bahwa profil kekuatan dan kelemahan anak autis ini bertujuan untuk menentukan rencana dan strategi penanganan untuk mendukung partisipasi anak di sekolah ataupun di tempat-tempat lain.

Setelah mengetahui profil kekuatan dan kelemahan anak, maka ibu dapat penjelasan yang lebih lanjut tentang penanganan yang tepat kepada orang-orang professional. Sastry \& Aguirre (2012) juga menjelaskan bahwa seorang neuropsikolog atau neurologi dapat membantu ibu memahami bagaimana otak dan sistem saraf anak autis bekerja. Seorang psikolog pendidikan dapat membantu ibu memahami bagaimana aspek-aspek kognitif dalam memengaruhi performa akademiknya, selain juga merekomendasikan keterampilan, minat dan kekuatan khusus yang dapat dibangun bagi pembelajaran anak. Seorang yang ahli dalam integrasi indra dapat membantu ibu memahami persoalan-persoalan fisik dan indrawi dan menginformasikan cara mengakomodasi dan menangani perilaku anak-anak 


\section{Nurussakinah Daulay}

autis. Terapis fisik akan mengidentifikasikan dan menangani fungsi fisik yang lemah melalui latihan dan penanganan fisik. Bagi ibu dan keluarga bahwa kerjasama dengan orang-orang profesional sangat membantu dalam mengoptimalkan anak autis.

Secara keseluruhan berdasarkan data demografi subjek penelitian menunjukkan bahwa ibu dengan kategori ketangguhan tinggi dapat terlihat dari aspek yang dominan yaitu berdasarkan usia yang lebih tua (berada pada tahap perkembangan dewasa akhir), bersuku Jawa, Minang, dan Bali, ibu dengan profil pekerjaan sebagai guru dan pegawai swasta, ibu yang berstatus janda disebabkan suaminya telah meninggal, berpenghasilan di bawah rata-rata, berpendidikan tinggi (S1), memiliki anak autis yang sedang berusia remaja, dan memiliki anak autis yang berjenis kelamin laki-laki.

Sedangkan pada ibu yang memiliki kategori ketangguhan sedang terlihat dari aspek yang dominan yaitu usia berada pada tahap perkembangan dewasa madya, bersuku Batak dan Tionghoa, profil pekerjaan sebagai Pegawai Negeri Sipil, Ibu Rumah Tangga, dan wiraswasta, ibu yang berpendidikan SMA, ibu yang memiliki 1 dan 2 anak. Terakhir pada ibu yang memiliki kategori ketangguhan rendah terlihat dari aspek yang dominan yaitu usia berada pada tahap perkembangan dewasa awal, bersuku Melayu, profil pekerjaan sebagai dokter, ibu yang berstatus telah bercerai, pendapatan perbulannya sebanyak Rp. 1.000.000Rp. 2.000.000, ibu yang memiliki jumlah anak lebih dari tiga, dan ibu yang memiliki anak autis dengan usia 0-5 tahun.

\section{Simpulan}

Hasil penelitian ini telah sesuai dengan tujuan penelitian yang dikemukakan sebelumnya, yaitu berupaya melihat gambaran profil ketangguhan pada ibu yang memiliki anak autis. Profil gambaran ibu memperlihatkan bahwa ibu cukup tangguh dalam mengasuh anak autis, meskipun terkadang ibu masih merasakan stres dan emosi negatif jika dihadapkan pada keadaan yang penuh tekanan. Untuk aspek komitmen, aspek kontrol, dan aspek tantangan juga berada pada kategori sedang. Penelitian ini penting untuk melihat sisi positif dari kepribadian ibu dalam berinteraksi dengan anak autis. Mengasuh anak autis bukan lah hal yang mudah, kompleksnya gangguan yang dialami anak autis seringkali membuat ibu mengalami kesulitan dalam mengasuh mereka, sehingga dibutuhkan kepribadian tangguh dalam mengatasi situasi yang menekan dan berdampak pada stres pengasuhan. Implikasi penelitian ini sebagai data awal untuk melihat gambaran profil ketangguhan ibu dalam mengasuh anak autis di kota Medan. 


\section{Gambaran Ketangguhan Ibu dalam Mengasuh Anak Autis}

Saran

Penelitian selanjutnya diharapkan dapat menggali lebih lanjut dengan wawancara mendalam untuk dapat menjelaskan faktor-faktor yang memengaruhi ketangguhan ibu, penggunaan koping agar ibu tetap tangguh, kondisi yang membuat tangguh dan tidak tangguh, dan harapan yang dimiliki ibu.

\section{Daftar Pustaka}

American Psychiatric Association. (2014). Diagnostic and statistical manual of mental disorders, 5th edition. Washington, DC: Author

Ambarini, T. K. (2013). Hubungan antara hardiness dengan tingkat stres pengasuhan pada ibu dengan anak autis. Jurnal Psikologi Klinis dan Kesehatan Mental. 02(2), 34-40.

Ahmad. (2015). Kecerdasan emosional dan hardiness pada ibu rumah tangga single parent. Psikologika. Jurnal Pemikiran dan Penelitian Psikologi, 20(1).

Azwar, S. (2012). Metode penelitian. Yogyakarta: Pustaka Pelajar.

Bartone, P.T., (1991). Development and validation of a short hardiness scale. Paper presented at the Third Annual Convention of the American Psychological Society, Washington, DC.

Bartone, P.T. (1995). A short hardiness scale. Paper presented at the meeting of American Psychological Society. New York: NY

Baird, G., Simonoff, E., Pickles, A. (2006). Prevalence of disorders of the autism spectrum in a population cohort of children in South Thames: the Special Needs and Autism Project (SNAP). The Lancet, 368 (9531): 210-254.

Billing, A. G., \& Moos, R. H. (1984). Coping, stres \& social resources among adults with unipolar depression. Journal of Personality and Social Psychology, 46(4), 877-891.

Bolte, S., Westerwald, E., \& Holtman, M. (2011). Autistic traits and autism spectrum disorders; the clinical validity of two measures presuming a continuum of social communication skills. Journal of Autism and Developmental Disorders 41(1): 66-72.

Center for Disease Control and Prevention. (2014). Prevalence of autism spectrum disodersautism and developmental disabilities monitoring network, 14 sites, United States, 2008. Morbility and Mortality Weekly Report, 61, 1-9.

Compton, W. C., Seeman, J., \& Norris, R. C. (1991). Predicting hardiness: A search for the parameters of deep cognitive structures. Medical Psychotherapy, 4, 121-130.

Dale, E., Johada, A., \& Knott, F. (2006). Mothers attributions following their child's diagnosis of autistic spectrum disorder. Autism, 10(5), 463-479.

Endraswara, S. (2012). Falsafah hidup Jawa: Menggali mutiara kebijakan dari intisari Filsafat Kejawen. Yogyakarta: Cakrawala. 


\section{Nurussakinah Daulay}

Estes, A., Munson, J., Dawson, G., Koehler, E., Zhou, X. H., Abbot, R. (2009). Parenting stress and psychological functioning among mothers of preschool children with autism and developmental delay. Autism. 13 (4): 473-387.

Fombonne, E. (2005). Epidemiology of autistic disorder and other pervasive developmental disorders. Journal of Clinical Psychiatry 66 (Suppl. 10): 3-8.

Gable, R., Wolf, M., \& Keilty, J., (1993). Instrument development in the affective domain (2nd Edition). Springer Science+Business Media, LLC. ISBN 978-94-011-1400-4 (eBook). http:/ / doi 10.1007/978-94-011-1400-4

Gentry, W. D., \& Oullette-Kobasa, S. C. (1984). Social and psychological resoucers mediating stress-illness relationships in humans. In W. D. Gentry (Ed). Handbook of behavioral medicine (pp.87-116). New York: Guilford.

Gray, D. E. (1994). Coping with autism: Stressess and strategies. Sociology of Health and Illness, 16 (3), 275-300.

Hattier, M. A., \& Matson, J. L. (2012) An examination of the relationship between communication and socialization deficits in children with autism and PDD-NOS. Research in Autism Spectrum Disorders, 6(2), 871-880.

Holzer, L., Mihailescu, R., Rodrigues-Degaeff, C., Junier, L., Muller-Nix, C., Halfon, O., \& Ansermet, F. (2006). Community introduction of practice parameters for autistic spectrum disorders: Advancing early recognition. Journal of Autism and Developmental Disorders, 36 (2), 249-262.

Judkins, S. K. (2001). Hardiness, stress, and coping strategies among mid level nurse managers: Implications for continuing higher education. Dissertation. Proquest.MI 48106-1346

Krissy, A. R., Tomas, D., Kushki, A., Duerden, E., Taylor, M., Lerch, J., Soorya, L., Wang, T., Fan, J., \& Anagnostou, E., (2012). The effect of diagnosis, age, and symptom severity on cortical surface area in the cingulate cortex and insula in autism spectrum disorders. Journal of Child Neurology 28(6), 732-739. http//.doi.org.10.1177/ 0883073812451496.

Kristine M. Kulage., Arlene M. Smaldone., \& Elizabeth G. Cohn. (2014). How will DSM 5 afect autism diagnosis? A systematic literature review and meta-analysis. Journal Autism Dev Disorder 44; 1918-1932. http//.doi.org.10.1007/s10803-014-2065-2

Kobasa, S. C. (1979). Stressful life events, personality, and health: An inquiry into hardiness. Journal of Personality and Social Psychology. 37, 1-11.

Kobasa, S. (1982). Commitment and coping in stress resistance among lawyers. Journal of Personality and Social Psychology, 42, 707-717.

Kobasa, S. C., Maddi, S. R., \& Kahn, S. (1982). Hardiness and health: A Prospective study. Journal of Personality and Social Psychology, 42, 168-177.

Kobasa, S. C., Maddi, S. R., Pucceti, M. C., \& Zola, M. A. (1994). Effectiveness of hardiness, exercise and social support as resources against illness. In A. Steptoe \& J. Wardle 


\section{Gambaran Ketangguhan Ibu dalam Mengasuh Anak Autis}

(Eds), Psychosocial processes and health: A reader (pp.247-260). Cambridge: Cambridge University Press.

Koentjaraningrat. (1990). Pengantar ilmu antropologi. Jakarta: Rineka Cipta.

Maddi, S. R. (2006). Hardiness: The courage to be resilient. I Thomas, J. C., Segal, D. L., Comprehensive Handbook of Personality and Psychopathology: Personality and Everyday Functioning, 1, 306-321. New York. John Wiley and Sons. Inc.

Maddy, S. R. \& Kobasa, S. C. (1984). The hardy executive, health under stress. Illinois: Dow Jones Irwin.

Martiarini, N. (2012). Pengatasan kelelahan ego (ego depletion) pada individu dalam konteks Budaya Jawa. (Tesis tidak dipublikasikan). Fakultas Psikologi, Universitas Gadjah Mada, Yogyakarta.

Matson, J. L., Hess, J., Neal, D., Mahan, S., \& Fodstad, J. C. (2010). Trend of symptoms in children diagnosed with autistic disorder as measured by the Autism Spectrum Disorder-Diagnostic for Children (ASD-DC). Journal of Developmental and Physical Disabilities, 22 (1), 47-56.

Matson, J. L., Kozlowski, A. M., Hattier, M. A., Horovitz, M., \& Sipes, M. (2012). DSM IV vs DSM V diagnostic criteria for toddlers with autism. Developmental Neurorehabilitation, 15(3), 185-190.

Maulana, M. (2014). Anak autis. Mendidik anak autis dan gangguan mental lain menuju anak cerdas dan sehat. Yogyakarta: Katahati.

Moore, A. (2010). Jenis kelainan pada anak. Jogjakarta: Kalamboti

Rahmah, A. (2012). Gambaran pola asuh ibu Suku Batak pada anak laki-aki dengan gangguan autis. Skripsi tidak dipublikasikan, Fakultas Psikologi, Universitas Sumatera Utara, Medan.

Santrock, J. W. (2002). Perkembangan masa hidup. Revisi 5. Jilid II. Jakarta: Erlangga.

Sastry, A., \& Aguirre, B. (2012). Parenting your child with Autism. Practical Solutions, strategies, and advice for helping your family. Oakland: New Harbinger Publications, Inc.

Sitorus, M. C., (2016). Gambaran stres pada ibu yang memiliki anak autis. Skripsi tidak dipublikasikan, Fakultas Psikologi, Universitas Sumatera Utara, Medan.

Stefani. (2012). Hubungan kejadian penyakit autistik pada anak dengan usia maternal dan paternal di Kota Medan. Diunduh dari: http://repository.usu.ac.id/handle/123456789/31119/ tanggal 1 Oktober 2016

Strutton, D., Pelton, L. E., \& Lumpkin, J. R. (1995). Personality characteristic and sales people's choice of coping strategies. Journal of the academy of marketing science. 23 (3). 132-140.

Taylor, S. T. (1995). Health psychology. 3rd Ed. New York: McGraww-Hill, Inc.

Volkmar, F., Siegel, M., Woodbury-Smith, M., King, B., McCracken, J., \& State, M. (2014). Practice parameter for the assessment and treatment of children and adolescents 


\section{Nurussakinah Daulay}

with autism spectrum disorder. Journal of the American Academy of Child and Adolescent Psychiatry, 53 (2), 237-257.

Weiss, M,J., (2002). Hardiness and social support as predictors of stress in mothers of typical children, children with autism, and children with mental retardation. Autism, 6 (1) 115-130; 021327 1362-3613 9200203) 6:1. 